Toby et al., 2021

Volume 6 Issue 3, pp. 269-283.

Date of Publication: $9^{\text {th }}$ February 2021

DOI- https://doi.org/10.20319/pijss.2021.63.269283

This paper can be cited as: Toby, B. G., Ajie C. E Nwanyanwu, M. E. (2021). Legal Protection of Internally Displaced Persons (IDPs) in Nigeria amidst Coronavirus (Covid-19) Pandemic. PEOPLE: International Journal of Social Sciences, 6(3), 269-283.

This work is licensed under the Creative Commons Attribution-NonCommercial 4.0 International License. To view a copy of this license, visit http://creativecommons.org/licenses/by-nc/4.0/ or send a letter to Creative Commons, PO Box 1866, Mountain View, CA 94042, USA.

\title{
LEGAL PROTECTION OF INTERNALLY DISPLACED PERSONS (IDPs) IN NIGERIA AMIDST CORONAVIRUS (COVID-19) PANDEMIC
}

\author{
Boma Geoffrey Toby \\ Senior Lecturer, PhD (ABSU, NIG), Department of Jurisprudence and International Law, Faculty \\ of Law, Rivers State University, Port Harcourt, Rivers State, Nigeria \\ tobybomag@yahoo.co.uk \\ Chukuma Ajie \\ Lecturer, PhD, Faculty of Law, Rivers State University, Nkpolu-Oroworukwo, Department of \\ Business Law, Port Harcourt, Nigeria \\ ajiechukuma@gmail.com

\section{Martina Ebikake Nwanyanwu} \\ Lecturer, PhD, Department of Business Law. Faculty of Law, Rivers State University, Nkpolu- \\ Oroworukwo, Port Harcourt, Nigeria \\ martinanwanyanwu11@gmail.com
}

\begin{abstract}
The sudden global attack of the COVID-19 virus came at the heels of 2019 and brought to the fore the need for a binding legal framework for the internally displaced persons scattered over various IDP camps Nationwide. The pandemic, in the face of poor living and congested temporary shelters unsuitable for living, poor sources of clean water, insufficient food provisions, sanitation and unhygienic amenities put the IDPs at greater risk than they were before this time. The known cure, for the time being, is social distancing, handwashing with water and soap and application of alcoholic based solutions regularly. In the light of the above, this paper examines briefly who the
\end{abstract}


homeless are in Nigeria, their challenges and the effect of the recent viral phenomenon; taking into cognizance their right to be protected under various treaties and soft laws discussed below. Recommendations are thus made for a concise binding and enforceable law or a review of existing soft laws which directly lack the force of law to be fully adopted through the necessary reception laws into Nigeria. This is believed will enhance protection of the displaced persons within the Nigerian space, especially during emergencies such as Coronavirus (COVID-19).

\section{Keywords}

COVID-19, Homeless, Internally Displaced, Vulnerable, Legal Protection, Nigeria

\section{Introduction}

At the close of 2018, Adrian (2019) reported that the UNHCR Yearly Global Trends Report found that 70.8 million children, women and men were forcibly displaced across the globe. This was considered the highest number in the organization's almost 70-year history, an increase of 2.3 million more than the previous year. According to Obinna, O. et al,(2020), over two million Nigerians have been displaced from their homes; especially from the Northeastern parts of Nigeria since 2009. Annually, millions of people, especially the vulnerable groups of women (widows), the poor and orphaned children who have become orphans as a result of displacement, are rendered homeless within Nigeria to temporary abodes and camps setup temporarily for them to cater for their needs in various regions of Nigeria. Factors such as insurgencies, Faith, et al (2019), violent outbreaks and similar crisis continue to play an active role in making cases of internal displacement a global problem and matters of international concern that is attracting legal attention like the refugees all over the world.

Those forced to leave their homes are resettled by government intervention mechanisms in vulnerable temporary settlements popularly referred to as the internally displaced camps and these camps are characterized by overcrowding and scarcity of basic infrastructures like standard healthcare services, clean water, and sanitary provisions. Access to these amenities are scarce and often a challenge prior to the emergence of COVID-19 virus pandemic. Typically, these vulnerable groups are usually rural settlers with little education to make a living in the camps, thereby depending more on donor organizations and humanitarian interventions than the government for relief supplies. In 2017, an estimated 4,800 suspected cases of Cholera outbreak and 61 deaths occurred in the Muna Garage Camp and other communities, home to 32,000 IDPs in the outskirt of 
Maiduguri in Nigeria. Displacement already leaves them disadvantaged in many ways, and with the recent global COVID-19 pandemic, their conditions are not only exacerbated, but their need for a concise legal protection in Nigeria is palpable.

\subsection{Implications of Displacement}

The Ministry of Women Affairs and Social Development estimates 17.5 million are orphans and vulnerable children (OVC) in Nigeria and ninety-five percent have no medical care, and no social, material, or no support is given to them to return to school while a quarter of them show symptoms of mild to moderate malnutrition. Childhood malnutrition according to USAID (2020) is also one of the causes of childhood deaths in Nigeria, the case in displacement camps and a condition that increases the poverty index of Nigerian. Rebecca, H. et al.(2012), reveal that about $54 \%$ of the Nigerian population remains in poverty, a vulnerable condition that affects the social sphere and despite Nigeria's relative wealth, it's current spending on social protection of her citizens is small compared to other African countries. Similarly, UNICEF reports that the above conditions have led to the death of millions, especially children and adolescents.

\subsection{Scope of Research}

This paper thus closely works through the situation of the internally displaced in Nigeria in the light of the foregoing and examines the legal provisions, if any, providing for their rights and protection. The effect of the recent COVID-19 virus outbreak on the homeless is also examined and a suggestion for a concise legal regime for the homeless that is tailored to their welfare is advocated, amongst others.

\subsection{Research Issues}

The vulnerable condition of those who have become homeless as a result of violent attacks within Nigeria and their protection before, during and after displacement has necessitated this research. Thus, the paper seeks the reason for their meagre protection especially during the COVID19 pandemic that is killing millions across the globe and finds a gap in their protection as a result of a lack of an enforceable law to protect their welfare and right to basic amenities like good sources of water for handwashing, hygienic environment to protect against the effect of the virus etc.

\subsection{Objective of Paper}

The object is to suggest that the legislature should promulgate good and enforceable law s to protect their displaced and vulnerable citizens in Nigeria. With such laws, the displaced would be able to enhance and enforce their rights to basic infrastructures like water, accommodation, healthy 
environment, and electricity and health services during the pendency or period of displacement and similarly, that the soft laws and treaties applicable to Nigeria on displacement be legislated into a binding and enforceable law on the subject.

\section{Methodology}

A doctrinal analysis is adopted to explain this research, the concepts and the entire issues raised in this paper for ease of readership. Works of authors in texts, books, journals and reports will be consulted and duly attributed. Statutory provisions are also consulted to complete this research. But first, a conceptual analysis of this work is examined hereunder for a better understanding of the discussion that follows.

\subsection{Conceptual Examinations}

This work is now turning attention to briefly discuss the following concepts; Covid-19 virus; its symptoms and the various measures to curtail its spread, some reasons for internal displacement will be examined alongside other emerging crises. This will be followed by a discussion of the legal framework on internal displacement in Nigeria which includes the NPIDP, the CFRN, 1999 (as amended) and the Kampala Convention, 2009 of the African Union as they apply to and affect the displaced in Nigeria.

\subsection{COVID-19 Viruses}

About 10months ago, the world witnessed a strange health emergency tagged COVID-19 otherwise known as Coronavirus disease, aptly described as a global epidemic believed to have started from the city of Wuhan, China in December 2019. It is currently a full-blown health challenge in almost all parts of the world including Nigeria. The NCDC, (2020) by 19 October 2020 , recorded a total number of Coronavirus cases of 61,558in Nigeria. The virus attack came with fear, panic and shock; claiming millions of lives across the world in so short a period. Countries like China, Italy and Spain, the US, UK and Nigeria are recording high incidences of the virus attack and deaths there from. As the virus spreads, healthcare systems are overwhelmed and more deaths continue to be recorded daily, making it a challenge to contain the virus spread. The Nigerian health care system battles to contain this risk daily with its ill-equipped health infrastructures to manage and surmount the pandemic in Nigeria. It is a health crisis which Nigeria was not prepared to overcome, especially for her vulnerable citizens. Health laboratory centers for testing and treatment 
(palliative) of the COVID-19 virus patients in Nigeria was a challenge in Nigeria, with only about 12 Functional testing centers across the thirty-six state of the country by April 2020.

\subsection{Symptoms}

Refugee International (2020) refers to the virus as a humanitarian crisis of the twenty first century, causing tones of human death. In addition, the National Centre for Disease Control (NCDC) calls it a novel strain of virus that has been previously identified in humans. According to them, the disease presents with mild to severe respiratory symptoms like fever, difficulty in breathing, with no specific vaccine, found for the treatment. However, many of the symptoms were managed during the heat of the attack and are still treatable.

Without a data of the displaced and widespread testing for COVID-19 in Nigeria, it could not be ascertained how the pandemic was not spreading nor appropriately respond to it. The risk remains high and most feared among the vulnerable citizens of Nigeria in IDP camps. These conditions trigger concerns as the internally displaced begged for governments support and protection especially during the heat period of the virus; a call for concern.

\subsection{Measures}

Many Nigerian state governments ordered a total and partial lockdown across its states, borders, ports, airways, markets and business places to encourage social distancing while washing of hands and the application of alcohol-based sanitizers continue remotely. Similarly, the covering of mouth, nose and hands and avoiding close contact with people are ongoing measures continues for over seven months now as ordered by the federal government and state governors in Nigeria, to continue the slowing process of the killer virus and to protect citizens.

\section{Internally Displaced Persons}

Archie, H. (Eds). (2001) describes the displaced as persons forced to abandon their homes because of natural disaster, war or persecution. When the term 'internal (ly)' is used in this paper, it is in respect to those' rendered homeless 'inside' Nigeria. The Internal Displacement Monitoring Center (IDMC), (2020) describes internal displacement as a person(s) who voluntarily abandon their homes in flight, in search of peace and better livelihood, to avoid being hurt by situations of violence or disasters, to other places of safety within Nigeria. The African Union, (2020), adds that they flee from their homes but do not cross an internationally recognized border and that internal 
displacement may be forced movement, evacuation or relocation of persons or groups of persons within internally recognized state borders.

The meaning of displacement is taking on new meanings to include residents of poor neighbourhoods who may temporarily due to impacts of poor weather, geographical or technological hazards, cases of draughts and environmental degradations; indigenous communities forced from their ancestral homes and those harassed constantly by local criminal groups become unsafe and unable to inhabit their usual places of residence, flee their homes but remain with the borders of their country and seek refuge somewhere therein, with hopes to return home as soon as it is safe to do so.

\subsection{Reasons for Homelessness}

According to IDMC, (2020), several reasons are responsible for driving people away from their homes. The National Policy on Internally Displaced Persons (2020) (NPIDP) gave reasons for displacements generally to include cases of conflicts fueled by wars, violence such as ethnic, religious, economic and boundary conflicts; insecurity and disasters. Similarly, environmental issues like climate change and government's violations of human rights within their own countries, as well as many other emerging reasons fuel conflict situations and make people flee their homes to temporary places of abode following internal wars and crises.

Internal displacement is adjudged one of the biggest and most overlooked challenges of the times. According to Kofi Annan, the former UN secretary-General internal displacement is a great tragedy of the time we live and those displaced are listed as part of the most vulnerable of the human family.

\subsection{Insecurity in Nigeria}

The World Bank's IBRD-IDA Report in 2019 denotes that Nigeria with over 200 million inhabitants accounts for half of West Africa's population and has one of the largest populations of youths in the world with a high expectancy for productivity and growth. Nigeria is a federation of multi-ethnic and culturally diverse people who face diverse fragile challenges of instability and insecurity of lives, properties that have driven people away from their communities and slowed down economic activities. The country's36 states make up six geo-political zones, that are plagued by several internal and externals conflict situations which have often triggered violence in several parts of the country. Early in 2019, the IDMC reports that 142,000 fresh cases have been driven 
homeless in Nigeria, while 140,000 were by conflict, 2,000 came by flood between January and February 2020.

\subsection{Insurgencies}

The activities of the Boko Haram Islamist sect have been largely credited as being responsible for pockets of instability in Nigeria in recent times. They have fueled several losses of lives and many cases of internal displacement in Nigeria, causing severe hardships as a consequence. It became full-blown in 2009 when their leader was dead while in detention. The remaining members ran out of Nigeria into the neighbouring African states and retrained themselves on how to use dangerous weapons; they also got more funding as well as connected themselves with mercenaries that have since metamorphosed into a deadly group causing violence and mayhem in the Nigerian society.

By 2014, DTM (2019) reports that Nigeria experienced the escalation of violence in Northeast Nigeria, resulting in mass displacement and deprivation of people in that region. Data

collected and accessed show a total number of displaced persons between $20^{\text {th }}$ October 2018 to January 2019, reflecting trends in most states as 1,948,349 individuals, a normal decrease of $4 \%$ or (78,253 persons) in the number recorded on the $25^{\text {th }}$ round of assessments, which identified 2 , 026,602, in keeping with a steady trend of increase from previous years. The decrease in number was as a result of the inability to assess 13 wards due to escalation of hostilities and insecurity.

The Boko Haram Islamists have contributed immensely to the displacement of persons in the northern part of Nigeria. For almost a decade, they have had a stronghold in this part of Nigeria and have displaced many. These persons are experiencing stressed outcomes with more need for increased support, following the outbreak of the COVID-19.

\subsection{Other Crises Situations}

In addition to the above, climate change and famine are specified under Sections 1.1.2 of the NPIDP, August 2012, as other causes of internal displacement in Nigeria. Further, conflicts with link to religious and political issues, natural disasters like flooding, erosion, oil spillage and development projects in the Niger Delta (South-South) all add to crises situations causing displacement. Subsection 8, Fulani herdsmen, farmer's attacks and armed groups as additional causes of displacement. In addition, in 2008over 400,000 people from Bakassi were returned to Nigeria from Cameroon following the ruling of the International Court of Justice on the 10th October 2002. Similarly, election related violence also leads to displacement. 
Further, the Policy guidelines also reported that extreme poverty and a lack of meaningful infrastructural development causes unemployment and annoyance among youths who resort to violence.

\section{Legal Protection}

This refers to the law; those rules or policies relating to law; connected with the law or its administration; deriving authority from law. Thus, in this sense, legal protection refers to those laid down rules by the governing authorities to safeguard people subject to it. Therefore, the homeless within the Nigerian border are merely displaced individuals and not refugees and do not enjoy a similar status of protection under international law as refugees. Notwithstanding, the Guiding Principles on Internal Displacement 1998, though non-binding, provides that IDPs are similarly entitled to enjoy protection without discrimination. The principle therein restates the rights of those arbitrarily displaced, it prohibits displacement on ethnic, religious or racial grounds. According to Wikipedia (2020), it is not easy to get an accurate figure of those internally displaced because of the population explosion which is not constant. Thus, there remains a huge gap in their protection globally and the unavailability of a universal treaty or law applicable to the internally displaced accounts for the huge gap recorded in their protection. Only regional treaties apply to them.

\section{Analysis of Findings}

The following findings were made on the legal instruments relating to IDPs in Nigeria. They Include the NPIDP, 2012, CFRN, 1919 (as amended) and the Kampala Convention, 2009 of the African Union and they are briefly discussed hereunder.

\subsection{National Policy on Internally Displaced Persons of August 2012 (NPIDP)}

The increasing incidence of forced displacement and it's the implication on lives and properties led the federal government of Nigeria to seeks ways to curb these incidences by legislating on a National Policy on Internally Displaced Persons (NPIDP) in August 2012. This is the strongest effort made on displaced persons, with contributions from several stakeholders; governments and organizations, which took into cognizance some UN's General Assembly guidelines on the prevention and management of internal displacement. 


\subsection{Focus of the Policy}

The above police serve as a National guideline to examine the root causes of internal displacement in Nigeria and its impact on those affected while seeking ways to assist those affected. The policy draft was revised in 2006 and 2012 respectively to reflect the emerging realities on displacement for the welfare of the displaced. Minimal efforts of government towards the welfare of the homeless is not enough to cushion the effect of displacement, as their condition remains precarious and requires more attention.

\subsection{Displaced Persons under the CFRN, 1999 (as amended)}

To achieve the lofty objectives and vision of the NPIDP, the Nigerian government is obliged to listen to the pleas of those homeless citizens. It provides for the recognition of those displaced as citizens and this is consistent with the provisions of the Constitution of the Federal Republic of Nigeria, 1999 (as amended), (CFRN). Their vulnerable state threatens their ability to provide to meet their basic needs while displaced, especially when families are torn apart and relatives killed or missing. The rights spelt out under Chapter 4 of the Constitution, especially on Fundamental Human Rights, including all other instruments to which all citizens of Nigeria are entitled, stands applicable to the internally displaced persons in Nigeria.

Section 3.1.2 of the NPIDP of August 2012, provides in addition, that IDPs have a right to be protected from displacement, in addition to the existing rights under Section 33-44, Chapter IV under Fundamental Human Rights, CFRN, 1999 (as amended). Similarly, Section 3.1.4 NPIDP adds that women have a right to be similarly protected, including those with disability and the elderly persons. Sadly, some state governments are unable and unwilling to provide for the welfare of the displaced their camps owing to a lack of a binding legal provision to hold them accountable.

It is found that a palpable gap exists in the protection of those displaced in Nigeria because there is no domestic law on the subject in Nigeria. However,

\subsection{Kampala Convention, 2009}

Though, there is no binding and enforceable domestic legal framework which directly provides for the protection of IDPs in Nigeria. Most of the laws on the subject are like soft laws and treaties with non-binding effect on the government and citizens. One of such treaty is the African Union, African regional treaty identified by Refworld, (2020), as the African Union Convention for the Protection and Assistance of Internally Displaced Persons in Africa, also referred to as (“Kampala Convention”) of $23^{\text {rd }}$ October 2009. This convention entered into force on 06 December 
2012 and Nigeria is a signatory to it. This means therefore that Nigeria is under obligation to respect and implement the provisions of the convention.

\subsubsection{Preamble}

African states which have ratified or acceded to the Kampala Convention are determined to adopt measures aimed at putting an end to the problem of internal displacement by eradicating the root causes such as persistent conflicts, natural disasters, insecurity and underdevelopment. This is in addition to the upholding the rights of the internally displaced without discrimination.

\subsubsection{Objectives of the Convention}

The objectives of the convention under Article 1 is primarily to promote and strengthen regional and national measures to prevent root causes of internal displacement as well as promote durable solutions to assist the displaced. State parties are also obligated to ensure respect for the convention, for human rights and dignity of the displaced, and respect for humanitarian instruments regarding protection and assistance in meeting the basis needs of the displaced.

As part of the obligation of the state parties, they are to ensure that their obligations under the convention is incorporated into domestic laws by enacting or amending relevant legislation on the protection of, an assistance to, internally displaced persons.

Under the Convention, states are also obligated to have the primary duty and responsibility for providing protection and assistance of IDPs within their territory without discrimination and they are to take measures to protect them among others.

\section{The Consequences of COVID-19 on IDPs in Nigeria}

The following discussion examines the result of coronavirus on those quarantined in the displaced camps in parts of Nigeria.

(i) Over-population

Internally displaced people live congested temporary houses where the amenities are not enough to serve all the inmates. Thus, several families share limited spaces, for example, bathroom, kitchen, tents. The ease with which the corona virus spreads makes this situation potentially disastrous to the IDPs.

(ii) Limited basic facilities 
Secondly, the forcibly displaced generally have access to merely primary healthcare. And do not have intensive care units where COVID-19 emergencies or existing health conditions of inmates of the camp can be properly taken care of. The existing centers are poorly managed.

(iii) Humanitarian Supply Chain Challenged

Government's restrictions on the travel of international personnel and the movement of vital supplies affected those in the displacement camps who rely on relief supplies from humanitarian sources for sustenance. Roads, rail and borders closures temporarily stopped transportation and the movement of goods and services, thereby interrupting supplies of relief supplies to those displaced. Scarcity of Good Water Supply

Basic healthcare infrastructure is disrupted at times of violence giving rise to poor sanitation and hygiene. At IDP camps there is a scarcity of good water supply and electricity to aid healthy practices like constant hand washing and toilet hygiene and some healthcare systems are destroyed during periods of hostility thereby causing deprivation.

(iv) Maternal Mortality

Pregnant women and children are not adequately provided for at the camps, causing a high mortality rate for those displaced in Nigeria. The number is high because of poor hygienic environment and food shortages causing malnutrition. The overcrowded camps and lack of good sanitary conditions make the pregnant IDPs susceptible to diseases and deaths even during the COVID-19.

(v) Joblessness, Unemployment and Homelessness

Displacement causes high cases of joblessness among the IDPs in Nigeria. Many who were working in companies or farming before the displacement has become unable to continue to work, farm or secure new employment. This increases the level of poverty.

(vi) Loss of loved ones, Affection and Family Life

Loved ones and families of IDPs suffer emotional traumas owing to the loss of their loved ones who may be missing in the cause of displacement, kidnapped or dead. Most are exploited, abused and raped at the camps and during the COVID-19; no Agency was allowed to carry out legal intervention on behalf of the abused.

(vii) Lack of Access to Justice

It is nearly and almost impossible to access justice as a displaced person in Nigeria, because the means of livelihood, homes are destroyed leaving IDPs at the mercy of the government, private 
individuals and donor who offer help at will. They become incapable of paying for legal services to fight for their rights or to seek justice.

(viii) Yearnings for the DPs

According to ICC Years 1920-2020, (2020)revealed that IDPs in Northeastern part of Nigeria are under risk, quoting an IDP as saying that the IDPs were not given any support or donation to provide for handwashing equipment's, yet the government is concerned with laying making emphasis observing the rules to prevent the virus. She questioned the safety of those in the camps will cope with the pandemic. Aisha Abubakar, another IDP from Nganzai was quoted to have lost all hope but in God.

\section{Government, Partner Organizations and COVID-19}

Under the Kampala Convention, (2020), governments are considered primarily responsible for the care of those displaced and to respect, protect and provide necessaries for the full enjoyment of displaced persons without discrimination. In Nigeria, the United Nations along with its partners worked to support the Borno state government and others in installing hand-washing stations in the camps and ensuring the supply of clean water, soap and education in dealing with the outbreak. Though there has not been any reported case of Coronavirus infection from the camps, besides no testing was carried out on person living in the camps.

The Borno state government however made efforts to disinfect the camps against the virus, with promises to frequently do more and create more shelters to end overcrowding and reduce human contacts at the camps in addition to improving sanitary facilities and provide necessary items such as single-use gloves, face mask, soap, contactless water taps across the state, temporary isolation tents and ambulances to convey and keep those who show symptoms of COVID 19 to be provided. In addition, a ban was placed on visits to IDP camps to curb the spread of the virus.

Those who voluntarily leave their homes because of violence situations suffer a lack of protection and other adverse environmental difficulties in shelters where they take refuge and require legal provisions to enhance their rights and obligations. But due to a lack of binding and enforceable legal regime, the problems enumerated above persist and the displaced persons continue to suffer. Their predicament is worsened with the emergence of the coronavirus Covid-19. The absence of a concise and binding legal framework on IDPs in Nigeria is a concern that calls for more action on the part of the government. The drafting of the Policy on Internally Displaced 
Persons in 2012 serves as a mere guide on issues of displacement in Nigeria. Its principle has no binding force of law. Therefore, it is advocated that urgent attention be given to the issues pertaining to the displaced in Nigeria and the following are recommended;

(A) That, palliatives (in terms of food and cash) usually given to displaced persons in times of crises should be such that genuinely addresses the health needs of the internally displaced persons in Nigeria. What is been done during this period is short of international humanitarian law standards, thus the need for urgency to address these shortfalls using the law against future occurrences.

(B) Professional Mediation and Arbitration services in times of crises and e.g. clauses in potential agreements and documents that are liable to erupt into violence between communities and individuals should be provided by the government to citizens in various states and local communities for implementation in communal relationships.

(C) Continuous Sensitization by the government on education, sensitization and counselling of the Nigerian populace against the ills and adverse consequences of violence and disagreements which can easily lead to displacement be put in place and implemented.

(D) The necessary reception legislations are put in place to receive relevant treaties and laws on IDPs into binding legislation.

(E) Access to clean water, soap, shelters, and nutritious food is also crucial to sustain the vulnerable people to build immunity against the Covid-19 virus and future outbreaks. Develop more awareness and sensitize with leaflets, posters, animations specifically for camp residents and carry out campaigns across various Nigerian states in special English and local languages at times of pandemics. The need for solutions in the form of better data and communication channels be properly developed and implemented to help everyone have a grasp of the full extent of any prevailing situation.

\section{Conclusion}

This paper examined the welfare and rights of the internally displaced in Nigeria with a view to the domestic legal framework providing for their protection and finds that there is no domestic law directly providing for their protection but that, soft laws and treaties are providing for the protection of Internally Displaced Persons such as the Kampala Convention 2009 to which Nigeria is a signatory. The convention lacks that binding force of law to compel states and 
government to be legally liable for infractions of the rights of the displaced, Nigeria is only under obligation to respect and implement it. This paper concludes by finding that the existing gap in the protection of the IDPs in Nigeria can be closed by domesticating the existing treaties or reviewing the existing soft laws to include the rights and assistance of the IDPs. This research also concludes by looking into the future scope of this research and their limitations as elucidated hereunder.

\subsection{Future Scope of Research}

Most importantly, however, will be how the majority of the poor in most of the remote rural communities in Nigeria are gainfully engaged to uphold peaceful actions in resolving conflict situation that metamorphose into violence and displacements. The consequences of violence to the Nigerian nation and its economy will be the future of discussion in this area.

\subsection{Research Limitation}

This study is limited to those displaced from their homes because of violent outbreaks that make them unsafe. The homeless groups who relocate to shelters with inadequate provisions and infrastructure causing severe hardships, poverty, increased number of deaths and exacerbated situations of insecurity during the coronavirus pandemic. Above all, there is a need to protect and assist millions of vulnerable women, poor and children, who deserve a brighter future as other citizens from the Nigerian government.

\section{REFERENCES}

Adrian, E. (2019).’UNHCR Global Forced Displacement Tops 70 Million” Retrieved 20 January

2021. https://www.unhcr.org/news/stories/2019/6/5d08b6614/global-forced-displacement-tops-70$\underline{\text { million.html }}$

African Union. African Union Convention for the Protection and Assistance of IDPs in Africa (“Kampala Convention") 23 $3^{\text {rd }}$ October 2009, entered in to force on 06 December 2012. Citied as https://www.refworld.org/docid/4ae572d82.html [assessed 24 December 2020].

Archie, H. (Eds). (2001). "The Oxford Dictionary of Difficult Words", New York, USA:

Constitution of the Federal Republic of Nigeria, 1999 (as amended) CSEA).

Displaced: Addressing the Threat of the Novel Coronavirus in Humanitarian Emergencies. Retrieved 30 March 2020 from https://www.refugeesinternational.org/reports/2020/3/29/covid-19-and-the-displacedaddressing-the-threat-of-the-novel-coronavirus-in-humanitarian-emergencies 
February 2020 from https://www.internal-displacement.org/internal-displacement/

Faith, O. et al., (2019). "Insurgency and the Invisible Displaced Population in Nigeria: A

Situational Issue: Sage Journal. Retrieved 20 January 2021

https://journals.sagepub.com/doi/full/10.1177/2158244019846207

Guiding Principles on Internal Displacement. (2020). Retrieved 1 April 2020 from

https://drc.ngo/media/1217434/guiding-principles-on-internal-displacement.pdf

https://www.aa.com.tr/en/africa/covid-19-idps-in-northeastern-nigeria-camps-under$\underline{\text { risk/1791254 }}$

https://www.spring-nutrition.org/publications/reports/review-programming-orphans-andvulnerable-children-nigeria

ICC Years 1920-2020. (2020). Covid-19: IDPs in North-Eastern Nigerian Camps

IDMC. (2020). Internal Displacement Monitoring Centre. Internal Displacement. Retrieved 19 November 2020.

Nairametrics, (2020). Retrieved 19 October 2020 from https://nairametrics.com/2020/10/20/covid-

19-update-in-nigeria/

National Policy on Internally Displaced Persons (IDPs), August 2012.

Nigeria. Retrieved 12 April 2020 from

Obinna, O. and Basil, A. (2020, April 15). Center for the Study of the Economics of Africa, Oxford Press. 134.

Rebecca, H. and Jessica, H. Z. (2012). Social Protection in Nigeria Synthesis Report.

Refugee International. (2020). Issue Brief, Report, 'COVID-19 and the Retrieved 1 April 2020 from https://www.odi.org/sites/odi.org.uk/files/odiassets/publications-opinion-files/7583.pdf

Reliefweb. (2017). “Cholera in Nigeria: An Outbreak Hits IDP Camps.” Retrieved 20 January 2021 from https://reliefweb.int/report/nigeria/cholera-nigeria-outbreak-hits-idp-camps 